\title{
Gambaran Hematologi Anemia Defisiensi Besi pada Anak
}

\author{
Widiaskara IM, * Pramitha PT, ${ }^{*}$ Bikin $S$, ${ }^{*}$ grasena IDG ${ }^{* *}$ \\ ${ }^{*}$ Bagian Ilmu Kesehatan Anak RSUD Wangaya, Denpasar. \\ **Departemen Ilmu Kesehatan Anak Fakultas Kedokteran Universtas Airlangga/RS Dr Sutomo, Surabaya
}

Latar belakang. Anemia defisiensi besi (ADB) menjadi masalah kesehatan di dunia, baik di negara maju maupun negara berkembang seperti di Indonesia. Sekitar 30\% penduduk dunia menderita anemia dan lebih dari setengahnya merupakan anemia defisiensi besi. Dampak negatif yang diakibatkan oleh anemia defisiensi besi pada anak balita sangat serius.

Tujuan. Mengetahui gambaran hematologis anemia defisiensi besi pada anak yang dirawat di RSUD Wangaya Denpasar.

Metode. Penelitian deskritif potong lintang, pada anak yang dirawat di RSUD Wangaya Denpasar pada periode Januari - Juni 2009, umur 6-59 bulan. Diagnosis anemia defisiensi besi berdasarkan kriteria WHO, diberikan pengobatan bagi yang menderita ADB dengan sulfas ferosus (SF) selama 1 bulan.

Hasil. Didapatkan 75 anak usia 6-59 bulan yang dirawat di RSUD Wangaya dengan anemia. Sebagian besar (52\%) laki-laki, terbanyak usia 12 - 35 bulan (46,7\%) dan 65,3\% menderita dengan rerata kadar $\mathrm{Hb}$, MCHC, SI, TIBC, saturasi transferin berturut-turut adalah 9,9 g/dl , 31,8 g/dl, 37,9 Ug/dl, $361 \mathrm{Ug} / \mathrm{dl}$ dan $12,3 \%$, HCT 30,7\% dan feritin serum 75,6 ug/L. Pengobatan dengan SF selama 1 bulan menunjukkan peningkatan $\mathrm{Hb} 1 \mathrm{gr} / \mathrm{dl}$ dan HCT 2,8\%.

Kesimpulan. Anak yang dirawat dengan anemia 65,3\% anemia defisiensi besi dan. sebagian besar $(57,1 \%)$ mempunyai status besi yang kurang. Selama 1 bulan pengobatan dengan sulfas ferosus terjadi peningkatan Hb 1 gr \% dan HCT 2,8\%. Sari Pediatri 2012;13(5):362-6.

Kata kunci: anemia defisiensi besi, balita

$\mathrm{P}$ ada bayi, kejadian ADB diperkirakan antara $20 \%-25 \%$. Di Indonesia, survei kesehatan rumah tangga tahun 1995 melaporkan $40,5 \%$ balita menderita $\mathrm{ADB}$

\section{Alamat korespondensi:}

Dr. I Made Widiaskara, Sp.A, Bagian Ilmu Kesehatan Anak RSUD Wangaya-Denpasar. Jalan Kartini Nomor 133 Denpasar Bali. Telp. (0361) 222487, Fax. (0361) 224114. E-mail: widiaskara@yahoo.com dan $47,2 \%$ anak usia sekolah. ${ }^{1,2}$ Pada penelitian yang dilakukan di Departemen Ilmu Kesehatan Anak FKUI terdapat 75\% (dari 47 anak) dengan $\mathrm{Hb}$ normal menderita ADB. ${ }^{3}$ Bhaskaram dkk, ${ }^{4}$ pada tahun 2003 melakukan penelitian pada 43 anak-anak usia 3 - 4 tahun mendapatkan $83 \%$ anak dengan pneumonia mempunyai $\mathrm{Hb}<11 \mathrm{~g} \%$. Ringo Ringo $^{5}$ mendapatkan $38,5 \%$ bayi umur $<6$ bulan di Banjarbaru menderita ADB. 
Dampak negatif yang diakibatkan oleh ADB pada anak balita berupa gangguan konsentrasi belajar, tumbuh kembang terganggu, penurunan aktifitas fisik maupun kreatifitas menurun, serta menurunkan daya tahan tubuh sehingga meningkatkan risiko infeksi. ${ }^{2,4}$

Atas dasar angka kejadian ADB yang tinggi dan dampak negatif yang ditimbulkannya, maka kami melakukan penelitian yang bertujuan untuk mendapatkan gambaran hematologi anemia defisiensi besi pada anak yang dirawat di RSUD Wangaya Denpasar.

\section{Metode}

Suatu penelitian potong lintang dengan subjek anak yang dirawat di bangsal Kaswari, Angsa dan Belibis RSU Wangaya Denpasar pada periode Januari - Juni 2009. Populasi target adalah anak balita yang dirawat di bangsal tersebut selama periode penelitian. Kriteria inklusi penelitian adalah anak usia 6-59 bulan dengan gambaran laboratorium $\mathrm{Hb}<11$ gr \%. Kriteria eksklusi penelitian yaitu anak yang secara klinis menunjukkan penyakit gangguan darah lain seperti thalassemia, hemophilia, dan leukemia atau data rekam medik tidak lengkap.

Menurut organisasi kesehatan dunia bagi anak berusia 6 bulan -6 tahun dikatakan anemia apabila kadar hemoglobin $<11 \mathrm{gr} / \mathrm{dl}$. Diagnosis ADB ditegakkan berdasarkan kriteria WHO, yaitu 1). Kadar Hb yang rendah sesuai usia, 2). rata - rata konsentrasi $\mathrm{Hb}$ eritrosit $(\mathrm{MCHC})<31 \%$, 3). Kadar Fe serum $<50 \mathrm{Ug} / \mathrm{dl}$, dan 4). saturasi transfirin (ST) $<15 \%$. Kriteria yang harus dipenuhi paling sedikit kriteria nomor 1,3 , dan $4 .{ }^{1,6}$

Pemeriksaan laboratorium meliputi darah lengkap (DL), kadar besi (SI), total iron bending capacity (TIBC), dan serum feritin. Status besi dinilai berdasarkan kadar SI, saturasi transferin (ST), dan ferritin serum. Feritin serum menunjukkan cadangan besi tubuh, status besi yang sangat kurang pada keadaan terinfeksi (feritin serum $<30 \mathrm{ug} / \mathrm{L}$,kurang (feritin serum $<273 \mathrm{ug} / \mathrm{L}$ ), dan status besi normal (feritin serum $\geq 273 \mathrm{ug} / \mathrm{L}$ ). ${ }^{7}$

Kadar besi dipakai untuk menilai 3 tahapan defisiensi besi yaitu tahapan I (deplesi besi) ditandai dengan berkurangnya cadangan besi, namun besi serum masih normal (SI : >60 Ug/dl). Tahap kedua I iron deficient erythropoietin didapatkan suplai besi yang tidak cukup untuk menunjang eritropoisis (SI : $40-<60 \mathrm{Ug} / \mathrm{dl}$ ) dan tahap ketiga bila besi yang menuju eritroid sumsum tulang sudah tidak cukup (SI $<40 \mathrm{Ug}$ / $\mathrm{dl}) .^{2}$ Saturasi transferin (ST) dihitung dengan membagi
SI dengan TIBC dikalikan 100\%. Status besi yang sangat kurang (ST $<7 \%)$, kurang (ST $7-<16 \%$ ) dan status besi normal (ST > $16 \%$ ). Status gizi ditetapkan berdasarkan berat badan terhadap tinggi badan berdasarkan kurva CDC 2000 (Waterlow). Pendidikan orang tua dinilai berdasarkan pendidikan formal orang tua dibagi dalam 3 kelompok yaitu pendidikan rendah (pendidikan formal sampai sekolah dasar), pendidikan menengah (pendidikan formal setingkat SMP dan SMA), pendidikan tinggi (pendidikan formal setingkat perguruan tinggi). Pengukuran atau pemeriksaan laboratorium untuk darah lengkap, serum iron (SI), TIBC, dan serum feritin menggunakan standar pemeriksaan laboratorium RSUD Wangaya Denpasar dan laboratorium swasta yang ada di Denpasar. Data dikumpulkan menggunakan formulir penelitian. Data diolah dan disajikan secara deskritif dalam bentuk tabel dan grafik.

\section{Hasil}

Selama periode penelitian dari bulan Januari sampai Juni 2009 terdapat 208 pasien yang dirawat di Ruang Anak RSUD Wangaya Denpasar, usia 6-59 bulan. Tujuh puluh lima anak dengan data lengkap dan

Tabel 1. Karakteristik subjek

\begin{tabular}{lll}
\hline Karakteristik & Jumlah & $(\%)$ \\
& & \\
\hline Usia anak (bulan) & & \\
$\quad$ - 11 & 28 & 37,3 \\
$\quad 12-35$ & 35 & 46,7 \\
$\quad 36-59$ & 12 & 16 \\
Jenis kelamin & & \\
$\quad$ Laki - laki & 39 & 52 \\
$\quad$ Perempuan & 36 & 48 \\
Status gizi & & \\
$\quad$ Baik & 51 & 68 \\
$\quad$ Kurang & 24 & 32 \\
Anemia ADB & 49 & 65,3 \\
Pendidikan orang tua & & \\
$\quad$ Rendah & 25 & 33,3 \\
$\quad$ Menengah & 42 & 56 \\
$\quad$ Tinggi & 8 & 10,7 \\
Diagnosis utama & & \\
$\quad$ Gastroenteritis akut & 23 & 46,9 \\
$\quad$ Bronkopneumonia & 14 & 28,6 \\
$\quad$ Kejang demam +ISPA & 7 & 14,3 \\
$\quad$ Demam Tifoid & 3 & 6,1 \\
$\quad$ Infeksi saluran kemih & 2 & 4,1 \\
\hline
\end{tabular}


memenuhi kriteria inklusi, dijadikan subjek penelitian. Di antara 75 anak empatpuluh sembilan (65,3\%) menderita anemia defisiensi besi. Sebagian besar 39 $(52 \%)$ anak adalah laki-laki dan 35 (46,7\%) berusia 12-35 bulan (Tabel 1). Gambaran hematologis tertera pada Tabel 2.

Sebagian besar 28 (51,7\%) pasien menunjukkan status besi yang kurang dengan kadar SI 40-<60 Ug/dl. Status besi juga dapat diketahui dari kadar feritin serum dan nilai saturasi transferin. Nilai saturasi transferin, $43(87,8 \%)$ adalah $7-<16 \%$ (Tabel 3).

Semua pasien yang menderita anemia defisiensi besi diberikan pengobatan sulfaferosus $3 \mathrm{mg} / \mathrm{kg}$ $\mathrm{BB} /$ hari setelah satu bulan tampak peningkatan hemoglobin dan hematokrit (Gambar 1).

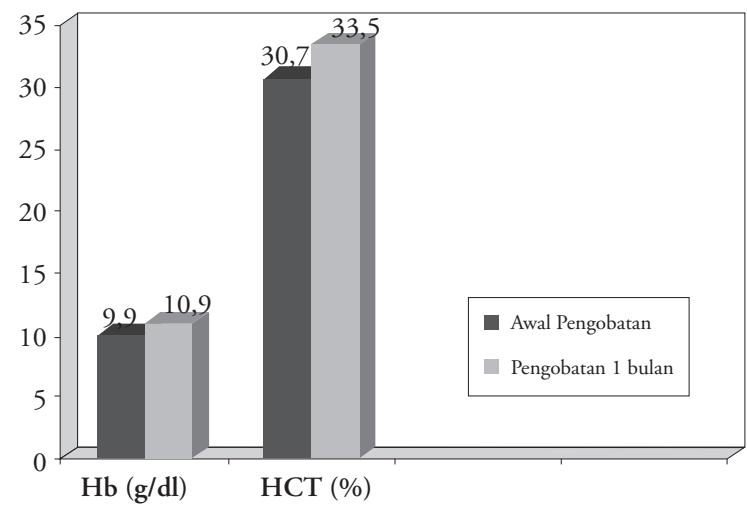

Gambar 1. Peningkatan hemoglobin dan hematokrit pada $\mathrm{ADB}$ sebelum dan sesudah pengobatan dengan sulfas ferosus 1 bulan

Tabel 2. Gambaran hematologi pada anemia

\begin{tabular}{lcc}
\hline Gambaran hematologi & $\begin{array}{c}\text { Anemia defisiensi besi (n=49) } \\
\text { Rerata }(\mathrm{SB})\end{array}$ & $\begin{array}{c}\text { Bukan anemia defisiensi besi }(\mathrm{n}=26) \\
\text { Rerata }(\mathrm{SB})\end{array}$ \\
\hline $\mathrm{Hb}(\mathrm{g} / \mathrm{dl})$ & $9,9(0,91)$ & $10,6(0,38)$ \\
$\mathrm{MCV}(\mathrm{Fl})$ & $70,8(7,32)$ & $75,5(7,89)$ \\
$\mathrm{MCH}(\mathrm{Pg})$ & $22,9(0,43)$ & $24,7(2,69)$ \\
$\mathrm{MCHC}(\mathrm{g} / \mathrm{dl})$ & $31,8(1,91)$ & $32,6(0,93)$ \\
$\mathrm{RDW}(\%)$ & $16,4(2,01)$ & $14,9(1,49)$ \\
$\mathrm{SI}(\mathrm{Ug} / \mathrm{dl})$ & $37,9(8,98)$ & $55,7(5,68)$ \\
TIBC $(\mathrm{Ug} / \mathrm{dl})$ & $361(48,32)$ & $293,7(49,86)$ \\
Saturasi transferin (ST) $(\%)$ & $12,3(11,71)$ & \\
Ferritin serum $(\mathrm{Ug} / \mathrm{l})$ & $75,6(51,4)$ & \\
HCT $(\%)$ & $30,7(2,2)$ & \\
\hline Ker & &
\end{tabular}

Keterangan:

Hb: Hemoglobin, MCV: Mean Corpuscular Volume; MCH: Mean Corpuscular Hemoglobin

MCHC: Mean Corpuscular Hemoglobin Concentration, RDW: Red cell Distribution Width, SI: Serum Iron, TIBC:

Total Iron Binding Capacity, ST: Saturasi Transferin, HCT: Hematocrit

Tabel 3. Gambaran status besi anak pada anemia defisiensi besi

\begin{tabular}{lcc}
\hline Status besi & Jumlah & $(\%)$ \\
\hline Besi serum (ug/dl) & & \\
$\quad<40$ & 21 & 42,9 \\
$\quad 40-<60$ & 28 & 57,1 \\
Saturasi transferin & & \\
$\quad<7$ & 6 & 12,2 \\
$\quad 7-<16$ & 43 & 87,8 \\
$\quad$ Ferritin serum ug/dl) & & \\
$\quad<30$ & 16 & 32,7 \\
$\quad 30-<273$ & 33 & 67,3 \\
\hline
\end{tabular}

\section{Pembahasan}

Anemia defisiensi besi di negara maju seperti Amerika Serikat pada tahun 2001 tercatat $9 \%$ anak berumur lebih dari 3 tahun dan 1\% wanita remaja menderita anemia defisiensi besi. ${ }^{1}$ Di Indonesia pada survai rumah tangga pada tahun 1999 menunjukkan bahwa 40,5\% anak balita dan $47,3 \%$ anak usia sekolah menderita anemia defisiensi besi. Survey pada anak sekolah dasar (1999) yang berumur 7-15 tahun menunjukkan 50\% anemia adalah anemia defisiensi besi. ${ }^{2,3}$

Pada anak usia 6 bulan -5 tahun penyebab anemia defisiensi besi adalah masukan besi kurang, kebutuhan yang meningkat karena infeksi berulang atau menahun, 
dan kehilangan berlebihan karena perdarahan antara lain karena infestasi parasit. ${ }^{67,8} \mathrm{Di}$ negara berkembang, infeksi akut relatif sering terjadi pada anak khususnya yang memiliki latar belakang ekonomi rendah. Bahkan infeksi ringanpun dapat secara signifikan menurunkan kadar $\mathrm{Hb}, \mathrm{Fe}, \mathrm{TIBC}$, dan sementara kadar FEP meningkat secara bermakna. ${ }^{9} 10$ Ramakrishnan dkk ${ }^{11}$ mendapatkan dengan ISPA bawah, 60\% di antaranya menderita anemia defisiensi besi dan 10\% oleh karena anemia penyakit kronis. Apabila ISPA bawah dibandingkan dengan kontrol disimpulkan bahwa anemia meningkatkan risiko ISPA bawah 5,75 kali.

De Pee $\mathrm{dkk}^{12}$ melaporkan prevalensi anemia pada bayi usia $4-5$ bulan di Jawa Barat, Jawa Tengah, dan Jawa Timur menunjukkan bahwa $37 \%$ bayi memiliki kadar $\mathrm{Hb}$ di bawah $10 \mathrm{~g} / \mathrm{dl}$, dan 71\% kadar $\mathrm{Hb}$ di bawah $11 \mathrm{~g} / \mathrm{dl}$. Ringo dkk $\mathrm{k}^{5}$ mendapatkan 38,5\% bayi berumur $<6$ bulan di Banjarbaru menderita anemia defisiensi besi. Pada penelitian kami dari 75 yang mendapat perawatan dengan anemia didapatkan 49 $(65,3 \%)$ diantaranya menderita ADB.

Defisiensi besi dapat terjadi karena (1) penurunan cadangan besi saat lahir (bayi prematur, gemeli, pendarahan perinatal, dan penjepitan umbilikus terlalu dini, (2) masukan besi kurang dan/atau ketersediaan besi dalam makanan rendah, (3) kebutuhan besi meningkat karena proses tumbuh kembang, dan (4) peningkatan kehilangan besi (akibat diare, perdarahan gastro intestinal). ${ }^{7,8,13}$

Pemeriksaan darah lengkap pada pasien anemia defisiensi besi dijumpai penurunan kadar $\mathrm{Hb}, \mathrm{MCV}$, $\mathrm{MCHC}, \mathrm{MCH}$ rendah, red cell distribution width (RDW) lebar, dan MCV rendah, merupakan uji tapis anemia defisiensi besi. Nilai RDW tinggi $>14,5 \%$ terdapat pada defisiensi besi, sedangkan RDW pada trait thalassemia pada umumnya normal (13\%). Apabila ratio MCV/RBC (indek Mentzer) $>13 \%$ dan RDW indek (MCV/RBC X RDW) 220, merupakan tanda anemia defisiensi besi. ${ }^{10}$

Terapi defisiensi besi meliputi dua komponen, yaitu koreksi defisiensi besi dan terapi penyebab yang mendasari. Suplementasi besi secara oral lebih dipilih daripada parentral karena dapat diabsorpsi dan ditoleransi dengan baik oleh anak. Pemberian zat besi pada anemia defisiensi besi bukan hanya sampai pada kadar $\mathrm{Hb}$ normal, namun harus dilanjutkan sampai cadangan besi terpenuhi. Pemberian zat besi sebaiknya diberikan dengan dosis 3-5 mg besi elemental/kg berat badan/hari. Untuk menilai hasil pengobatan dilakukan pemeriksaan $\mathrm{Hb}$ dan jumlah eritrosit. ${ }^{2,14}$ Syamsi $^{15}$ memperlihatkan bahwa suplementasi zat besi selama 30 hari pada anak dengan defisiensi besi di bawah usia 3 tahun tidak menunjukkan perkembangan fungsi kognitif yang bermakna.

Desai $\mathrm{dkk}^{9}$ melaporkan bahwa terapi pemberian suplemen besi setiap hari selama 6 minggu pada anak balita dengan anemia ringan hingga sedang di Kenya Barat, lebih baik, dibandingkan pemberian suplemen besi dua kali seminggu. Penelitian lain menunjukkan bahwa pemberian besi $3 \mathrm{mg} / \mathrm{kg}$ BB/hari selama 4 bulan pada bayi dan anak yang menderita anemia akan terjadi peningkatan kadar $\mathrm{Hb}$ secara bermakna $(3,8 \mathrm{gr} / \mathrm{dl}$ dari $9,5-12,3 \mathrm{gr} / \mathrm{dl}){ }^{6}$

Sedangkan pada penelitian kami mendapatkan peningkatan $\mathrm{Hb} 1 \mathrm{~g} \%$ dan HCT 2,8\% dengan pemberian besi 3-5 $\mathrm{mg}$ besi elemental/kg berat badan /hari selama satu bulan.

\section{Kesimpulan}

Anak usia 6-59 bulan yang dirawat 65,3\% anemia defisiensi. Selama pengobatan satu bulan dengan sulfas ferosus $3 \mathrm{mg} / \mathrm{kg} \mathrm{BB} /$ hari terjadi peningkatan kadar hemoglobin $1 \mathrm{~g} \%$ dan hematokrit 2,8\%. Angka kejadian ADB di RSUD Wangaya pada masa anak cukup tinggi dan perlu dicermati dampak negatif yang ditimbulkannya. Oleh karena itu perlu upaya menurunkan kejadian ADB dengan melakukan skrining awal terhadap anak yang berisiko serta pemberian suplementasi besi.

\section{Daftar pustaka}

1. WHO, Iron efficiency Anemia Assesment, Prevention and Control A guide for Programme Managers. WHO/ NHD/01.3. General English Only ; 2001 diunduh dari: http//www.google.co.id.htm.

2. Raspati H. Anemia defisiensi besi. Dalam : Permono HB, Sutaryo, Ugrasena IDG, Windiastuti E, Abdulsalam M, penyunting. Buku Ajar Hematologi Onkologi Anak. Edisi ke-2. Jakarta: BP IDAI; 2006.h.30-4.

3. Djajadiman Gatot. Diagnosis Anemia Besi pada anak : Pendidikan Kedokteran Berkelanjutan IKA X, Workshop Hemato - Onkologi. Sanur, IDAI Cabang Bali; 2010

4. Bhaskaram P, Nair KM, Balakhrishman, Sisikeran B. Serum transferring receptor in children with respiratory infeksion.EJCN 2003;57:75-80. 
5. Ringoringo HP, Windiastuti E. Profil parameter hematologi dan anemia defisiensi bayi berumur $0-6$ bulan di RSUD Banjarbaru. Sari Pediatri 2006;7: 214 - 7.

6. Soemantri Ag. Epidemiologi of iron deficiency anemia. Dalam: Rina Triasih, penyunting. Anemia defisiensi besi. Yogyakarta: Bagian IKA FK UGM;2005.h. 8-28.

7. Abdulsalam M. Diagnosis, Pengobatan dan pencegahan anemia defisiensi besi pada bayi dan anak. Dalam : Rina Triasih, Editor. Anemia defisiensi besi. Yogyakarta: Bagian IKA FK UGM; 2005: h.55-64.

8. Pudjiadi AH, Badriul Hegar, Setyo Handryastuti. Anemia defisiensi besi. Dalam: Pedoman pelayanan medis, Jilid I Jakarta: BP IDAI; 2010.h.10-3.

9. Ramakrishnan K. Haris PS. Hematologi level of risk faktor for lower respiratory tract infection. Indian J Pediatr 2006;73:881 - 3.

10. Kenneth R, Howard A. Anemias and other red cell disorders. The Mc Graw-Hill companies;2008.h.99 -114.

11. Desai Mr, Dhar R, Rosen DH, Kariuki SK, Shi Ya Ping,
Kager PA, Kunle FO. Daily iron suplementation is more efficacious than twice weekly iron supplementation for the treatment of childhood anemia in western Kenya. J Nutr 2004;134:1167-74.

12. De pee S, Bloem MW, Sari M,Kiess L,Yip R,Kojen S. The high prevalence of low hemoglobin concentration among Indonesian infants age 3-5 mounth is related to maternal anemia. J Nutr 2002;132:2215-21.

13. Lozoff B, Andraca I, Castilo M, Smith BS, Walter T, Pino P. Behavioral and development effects of preventing iron deficiency anemia in healthy fullterm infants. Pediatrics 2003;12:846-54.

14. Iwan Dwiprahasto. Terapi anemia defisiensi besi berbasis bukti. Dalam : Rina Triasih, prnyunting. Anemia defisiensi besi. Yogyakarta: Bagian IKA FK UGM; 2005.h.65-77.

15. Syamsi BR, Sutaryo. Hubungan defisiensi besi dengan perkembangan fungsi kognitif. Dalam: Rina Triasih, penyunting. Anemia defisiensi besi.Yogyakarta: Bagian IKA FK UGM; 2005.h.41-54. 